\title{
ANALISIS DUKUNGAN KELUARGA TERHADAP TINGKAT KEKAMBUHAN ORANG DENGAN GANGGUAN JIWA (ODGJ) DI WILAYAH KERJA PUSKESMAS GENENG KABUPATEN NGAWI
}

\section{Analysis of Family Support on The Level of Recurrent People with Mental Disorders in Work Area of Puskesmas Geneng}

\author{
Endri Ekayamti \\ Akademi Keperawatan Pemeritah Kabupaten Ngawi
}

\section{Riwayat artikel}

Diajukan: 18 Maret 2021

Diterima: 19 July 2021

\section{Penulis Korespondensi:}

- Endri Ekayamti

- Akademi Keperawatan Pemeritah Kabupaten

Ngawi

- e-mail:

Yamti.endrieka@gmail. com

\section{Kata Kunci:}

Dukungan Keluarga, Tingkat Kekambuhan, ODGJ

\begin{abstract}
Abstrak
Pendahuluan :. Dukungan keluarga yang baik akan membantu mempercepat proses pemulihan dan dapat menjegah terjadinya kekambuhan. Apabila orang dengan gangguan jiwa mengalami kekambuhan hal ini akan memperparah penyakit dan kemungkinan untuk sembuh menjadi lebih sulit. Tujuan penelitian ini untuk menganalisis hubungan antara dukungan keluarga yang meliputi dukungan penilaian, dukungan emosional, dukungan informasional dan dukungan instrumental dengan tingkat kekambuhan pada ODG. Metode: Populasi dalam penelitian ini adalah keluarga dengan angota keluarga yang mengalami gangguan jiwa yang berada diwilayah kerja Puskesmas Geneng Kabupaten Ngawi yang berjumlah 100 orang, dan hasil penghitungan besar sampel didapatkan 80 responden. Tehnik pengambilan sampel dengan purposive sampling. Pengumpulan data menggunakan kuesioner pada setiap variable dan kemudian dilakukan uji statistic dengan chi square . Hasil: didapatkan terdapat hubungan yang bermakna pada dukungan penilaian terhadap tingkat kekambuhan dengan nilai $\mathrm{p}=0,001 \quad(\mathrm{p}<0,05)$, dukungan emosional dengan nilai $\mathrm{p}=0,001(\mathrm{p}<0,05)$, tidak terdapat hubungan antara dukuangan instrumental terhadap tingkata kekambuhan ODGJ dengan nilai $\mathrm{p}=0,131(\mathrm{p}>0,05)$, dan terdapat hubungan yang signifikan antara dukuangan informasional terhadap tingkat kekambuhan ODGJ dengan nilai $\mathrm{p}=0,003 \quad(\mathrm{p}<0,05)$.. Kesimpulan: dukungan keluarga sangat berpengaruh terhadap tingkat kekambuhan pada ODGJ, dimana semakin baik dukungan yang diberukan keluarga tingkat kekambuhan berulang pada ODGJ dapat dihindari.
\end{abstract}

\section{Abstract}

Background: Good family support will help speed up the recovery process and can prevent relapse. If people with mental disorders experience a relapse, this will exacerbate the disease and make recovery more difficult. The purpose of this study was to analyze the relationship between family support which includes assessment support, emotional support, informational support and instrumental support with the recurrence rate in ODGJ. Method: The population in this study were families with family members with mental disorders in the working area of the Geneng Public Health Center, Ngawi Regency, amounting to 100 people, and the results of the calculation of the sample size obtained 80 respondents. The sampling technique is purposive sampling. Collecting data using a questionnaire on each variable and then carried out statistical tests with chi square. Results: The results showed that there was a significant relationship between assessment support for the recurrence rate with a value of $p=0.001(p<0.05)$, emotional support with a value of $p=0.001$ ( $p<0.05)$, there was no relationship between instrumental support and the rate of recurrence. ODGJ with a $p$ value $=0.131(p>0.05)$, and there is a significant relationship between informational support on the recurrence rate of $O D G J$ with a $p$ value $=0,003$ ( $p<0.05$. Conclusion: that family support is very influential on the rate of recurrence in ODGJ, where the better the support provided by the family, the rate of recurrence in ODGJ can be avoided. 


\section{PENDAHULUAN}

Masalah gangguan jiwa saat ini terus mengalami peningkatan. Peningkatan angka kejadian gangguan jiwa terjadi pada beberapa Negara di dunia dan termasuk Indonesia. Gangguan jiwa dapat terjadi karena adanya factor pemicu atau pencetus dimana salah satunya adalah dari fungsi afektif dalam keluarga yang tidak dapat berjalan dengan baik. Dimana gangguan pada fungsi afektif dalam keluarga akan berdampak terhadap seluruh fungsi keluarga tersebut (Nasir \& Muhith, 2011).

Keliat et al., (2011) menyebutkan kumpulan dari gejala dan pola perilaku yang berhubungan dengan distress maupun penderitaan pada seseorang sehingga menimbulkan suatu gangguan pada beberapa fungsi kehidupan disebut sebagai suatu gangguan jiwa. Apabila seseorang mengalami gangguan jiwa, maka perlu waktu yang panjang dan lama didalam proses pemulihan maupun proses penyembuhannya. Oleh karena itu dukungan keluarga sangat diperlukan pada ODGJ karena hal ini akan menentukan keberhasilan didalam pengobatan penderita (Maramis 2009). Dukungan keluarga sangat diperlukan pada ODGJ. Keluarga adalah kelompok terkecil dari penderita karena keluarga adalah tempat pertama kali ODGJ berinteraksi setelah setelah keluar dari rumah sakit dan juga sebagai tempat yang paling tepat untuk ODGJ untuk dapat menyesuaikan diri dengan lingkungan.

World Health Organization (WHO) tahun 2018, menuliskan terdapat satu dari empat orang didunia yang mengalami masalah mental, dan saat ini sekitar 450 juta orang diseluruh dunia mengalami gangguan jiwa. Data Riskesdas (2018) prevalensi gangguan jiwa di jawa timur meliputi skizofrenia/psikosis sejumlah 29.228 (6,40\%), Depresi 74.657 (4,53\%), gangguan mental emosional sejumlah $74.657(6,82 \%)$. Pada kabupaten Ngawi sendiri prevalensi gangguan jiwa skizofrenia/psikosis sejumlah 671 (2,43\%), depresi sejumlah 1.619 (3,58\%), dan gangguan mental emosional 1.619 (5,05\%). Prevalensi gangguan jiwa wilayah perkotaan terlihat lebih tinggi dibandingkan pedesaan. Proporsi rumah tangga didaerah pedesaan dengan gangguan jiwa skizofrenia/psikosis mencapai $6,6 \%$, sedangkan diperkotaan dengan proporsi $6,1 \%$. Dari hasil tersebut dapat disimpulkan bahwa tekanan hidup yang dialami penduduk perkotaan lebih tinggi dibandingkan dengan masyarakat pedesaan.

Masalah kesehatan jiwa tidak hanya dari gejala kejiwaan saja, bisa tingkat ringan seperti kecemasan dan depresi, konflik dengan teman kerja, terlalu sering marahmarah, ketagihan NAPZA, alcohol, dimensia pada orang tua, autisme, sampai pada kasus yang berat yaitu skizofrenia (Tiara et al., 2020). Hasil pengamatan ODGJ yang dinyatakan sembuh oleh pihak Rumah sakit seringkali tidak ada keluarga yang menjemput, begitu juga ketika ODGJ sudah berada dirumah, mereka kurang mendapatkan perhatian dari pihak keluarga, bahkan ada beberapa pasien yang mendapatkan diskriminasi dari keluarga sendiri. Kondisi tersebut dapat menyebabkan kekambuhan pada penderita. Kekambuhan merupakan keadaan dimana timbulnya kembali suatu penyakit pada seseorang yang sudah dinyatakan sembuh karena beberapa factor penyebab (Mubin et al., 2019). Kejadian kambuh pada masalah jiwa kronis diperkirakan 50\% akan muncul di tahun pertama, ditahun ke dua diperkirakan kejadian kambuh sebesar $75 \%$. Angka kekambuhan secara global pada penderita diperkirakan mencapai $50 \%$ sampai 92\%, dimana salah satu penyebabnya adalah kurang patuhnya penderita untuk berobat secara rutin, serta juga disebabkan karena kurangnya dukungan dari orang sekitar (Sheewangisaw, 2012). Orang dengan gangguan jiwa apabila mengalami kekambuhan maka akan memerlukan waktu yang lebih panjang dan lama untuk mengembalikan mereka pada keadaan pulih, dan apabila kekambuhan berulang atau lebih sering akan semakin memperburuk keadaan ODGJ sehingga kemungkinan untuk 
sembuh seperti keadaan semula menjadi sulit (Edelman et al., 2010)

Kekambuhan pada ODGJ akan berdampak terhadap pasien maupun keluarga. Pada ODGJ dapat berakibat tidak mampu bekerja (72\%), direhospitalisasi (69\%), percobaan bunuh diri $(22 \%)$ dan pada gangguan jiwa berat dapat perlakuan pasung (20\%). Karena keluarga adalah tempat terbaik untuk orang dengan gangguan jiwa. Salah satu upaya yang dapat dilakukam untuk mencegah kekambuhan dan membantu penyembuhan pasien adalah dengan dukungan keluarga. Berada diantara keluarga, ODGJ akan mendapatkan perhatian, cinta dan kasih sayang, hal ini akan sangat membantu mempercepat proses penyembuhan ODGJ. Keluarga adalah sumber dukungan utama dan juga sumber dukungan social yang penting terhadap ODGJ. Freadman menyatakan dukungan social dapat menurunkan dampak stress yang ditimbulkan dan secara langsung memperkuat kesehatan jiwa individu serta keluarga. Strategi preventif untuk mengurangi tingkat stress serta dampak negatifnya dapat diantisipasi dengan dukungan keluarga (Keliat et al., 2011). Bentuk dukungan keluarga dapat berupa informasi verbal maupun nonverbal, saran, bantuan langsung, ataupun dengan perilaku yang ditunjukkan oleh anggota keluarga yang lain akan memberikan dukungan dalam bentuk keuntungan secara emosional sehingga akan mempengaruhi perilaku ODGJ

Keluarga merupakan kelompok terkecil dan kelompok yang paling dekat dengan ODGJ dan dapat dikatakan sebagai perawat utama. Keberhasilan perawatan terhadap ODGJ dari Rumah Sakit akan siasia apabila tidak dilanjutkan oleh keluarga dirumah, dan hal ini dapat berakibat ODGJ mengalami kekambuhan. Peran serta keluarga yang diberikan sejak dini dalam perawatan pasien kemungkinan untuk kambuh bisa dicegah (Rahmayani \& Hanum, 2018). Dukungan yang diberikan keluarga dapat berupa sikap, tindakan, serta penerimaan keluarga terhadap ODGJ.
Kemenkes RI (2018) menyatakan dukungan keluarga sejalan dengan bentuk dukungan social yang meliputi dukungan emosional, dukungan informative, dukungan instrumental dan dukungan penghargaan. Dukungan keluarga dapat memberikan kekuatan terhadap individu, menciptakan kekuatan keluarga, penghargaan terhadap diri menjadi meningkat, serta dapat digunakan sebagai strategi untuk pencegahan utama terhadap keluarga untuk menghadapi tantangan kehidupan seharihari (Pratama \& Syahrial, 2015). Berdasarkan uraian diatas tujuan dari penelitian ini adalah untuk mengetahui dukungan keluarga yag dilihat dari dukungan penghargaan, emosioanal, informasional, dan instrumental terhadap tingkat kekambuhan ODGJ diwilayah kerja Puskesmas Geneng Kecamatan Ngawi .

\section{METODE}

Penelitian ini termasuk dalam jenis penelitian kuantitatif, yaitu metode penelitian dengan pengolahan statistika yang dianalisa dengan menggunakan angka. Desain yang digunakan adalah penelitian korelasional yang bertujuan untuk mengetahui ada tidaknya hubungan antar variable, dengan pendekatan crosscestional yang hanya menekankan pengukuran pada sekali waktu pengukuran.

Populasi dalam penelitian ini adalah keluarga dengan anggota keluarga yang mengalami ganguan jiwa diwilayah puskesmas Geneng Kabupaten Ngawi sebesar 100 orang, dan hasil penghitungan rumus besar sampel yang di gunakan sebanyak 80 responden, dengan kriteria responden meliputi: keluarga dengan anggota keluarga gangguan jiwa, keluarga tinggal satu rumah dengan ODGJ, dan bersedia menjadi responden penelitian. Tehnik sampling yang digunakan adalah pusposive sampling .

Variable bebas dalam penelitian ini yaitu dukungan keluarga yang meliputi dukungan penilaian, dukungan emosional, dukungan instrumental dan dukungan informative, sedangkan variable terikatnya 
yaitu tingkat kekambuhan ODGJ. Instrument penelitian terdiri dari kuesioner dukungan keluarga yang meliputi dukungan penilaian dengan jumlah 6 pernyataan. Dukungan emosional 6 pernyataan, dukungan informasional 7 pernyataan, dan dukungan instrumental 6 pernyataan.

Pengumpulan data menggunakan kuesioner yang diberikan oleh peneliti secara langsung dari rumah ke rumah kepada anggota keluarga dengan keluarga yang menalami gangguan jiwa. Selanjutnya data yang terkumpul dilakukan pengolahan dan dilakukan uji statistic menggunakan analisa chi square untuk mengetahui apakah ada hubungan antara dukungan penilaian, dukungan emosional, dukungan instrumental dan dukungan informasional dengan tingkat kekambuhan ODGJ

\section{HASIL PENELITIAN}

Tabel 1. Distribusi Karasteristik Keluarga dengan Anggota Keluarga yang Mengalami Gangguan Jiwa $(\mathrm{n}=80)$

\begin{tabular}{lll}
\hline Variabel & $\mathrm{N}$ & $\%$ \\
\hline Lenis Kelamin & & \\
Laki-laki & 60 & $75 \%$ \\
Perempuan & 20 & $25 \%$ \\
Umur & & \\
20-30 Tahun & 10 & $12 \%$ \\
31-50 Tahun & 52 & $65 \%$ \\
>50Tahun & 18 & $23 \%$ \\
Pendidikan & & \\
SD & 59 & $73,8 \%$ \\
SMP & 14 & $17,5 \%$ \\
SMA & 4 & $5 \%$ \\
PT & 3 & $3,8 \%$ \\
\hline
\end{tabular}

Sumber: Hasil Pengolahan Data, 2021

Pada tabel 1 dapat dilihat bahwa berasarkan jenis kelamin sebagian besar responden dengan jenis kelamin laki-laki sejumlah 60 (75\%) responden. Berdasarkan karakteristik umur sebagian besar responden berusia antara 31-50 tahun atau dalam kategori dewasa sejumlah 52 (56\%), untuk tingkat pendidikan mayoritas responden berada pada pendidikan SD yaitu sejumlah 59 $(73,8 \%)$ responden

Berdasarkan table 2 dapat dilihat dari 80 responden, sebagian besar responden berada dalam kategori dukungan penilaian baik sejumlah 48 (60\%) responden, dukungan emosional baik sejumlah 65 $(81,3 \%)$, dukungan.

Table 2 Distribusi Frekuensi Dukungan Keluarga dan Tingkat Kekambuhan Orang dengan Gangguan Jiwa ( $\mathrm{N}=80)$

Dilihat dari Tabel 2 distribusi frekuensi diatas menunjukkan rata-rata sampel $n=96$

\begin{tabular}{|c|c|c|c|}
\hline No & $\begin{array}{c}\text { Dukungan } \\
\text { Keluarga }\end{array}$ & Frekuensi & $\begin{array}{c}\text { Persentase } \\
(\%)\end{array}$ \\
\hline \multirow[t]{4}{*}{1} & Dukungan & & \\
\hline & Penilaian & & \\
\hline & Baik & 48 & $60 \%$ \\
\hline & Kurang & 32 & $40 \%$ \\
\hline \multirow[t]{4}{*}{2} & Dukungan & & \\
\hline & Emosional & & \\
\hline & Baik & 65 & $81,3 \%$ \\
\hline & Kurang & 15 & $18,8 \%$ \\
\hline \multirow[t]{4}{*}{3} & Dukungan & & \\
\hline & Instrumental & & \\
\hline & Baik & 24 & $30 \%$ \\
\hline & Kurang & 56 & $70 \%$ \\
\hline \multirow[t]{4}{*}{5} & Dukungan & & \\
\hline & Informasional & & \\
\hline & Baik & 60 & $75 \%$ \\
\hline & Kurang & 20 & $25 \%$ \\
\hline \multirow[t]{4}{*}{6} & Tingkat & & \\
\hline & Kekambuhan & & \\
\hline & Sering & 30 & $37,5 \%$ \\
\hline & Jarang & 50 & $62,5 \%$ \\
\hline
\end{tabular}

instrumental kategori baik sejumlah 24 (30\%), dukungan informasional kategori baik 60 (75\%), sedangkan responden dengan kategori dukungan kurang pada dukungan penilain sejumlah 32 (40\%), dukungan emosional sejumlah 15 (18,8\%), dukungan instrumental 56 (70\%), dukungan informasional 20 (25\%).

Pada frekuensi tingkat kekambuhan ODGJ sebagian besar berada pada tingkat kekambuhan jarang yaitu sejumlah 50 $(62,5 \%)$ orang. 
Tabel 3 Hubungan Dukungan penilaian, dukungan emosional, dukungan instrumental, dan dukungan informasional dengan Tingkat Kekambuhan Pada Orang Dengan Gangguan Jiwa $(\mathrm{N}=80)$

\begin{tabular}{|c|c|c|c|c|c|c|}
\hline \multirow{3}{*}{ Variabel } & \multicolumn{4}{|c|}{ Tingkat kekambuhan } & \multirow{3}{*}{ Total } & \multirow{3}{*}{ p-value } \\
\hline & \multicolumn{2}{|c|}{ Sering } & \multicolumn{2}{|c|}{ Jarang } & & \\
\hline & II & $\%$ & $\mathbb{1}$ & $\%$ & & \\
\hline \multicolumn{7}{|l|}{ Dukungan Penilaian } \\
\hline Baik & 11 & 13,75 & 37 & 46,25 & 48 & 0,001 \\
\hline Kurang & 19 & 23,75 & 13 & 16,25 & 32 & \\
\hline \multicolumn{7}{|l|}{ Dukungan Emosional } \\
\hline Baik & 19 & 23,75 & 46 & 57,5 & 65 & 0,001 \\
\hline Kurang & 11 & 13,75 & 4 & 5 & 15 & \\
\hline \multicolumn{7}{|l|}{ Dukungan Instrumental } \\
\hline Baik & 12 & 15 & 12 & 15 & 41 & 0,131 \\
\hline Kurang & 18 & 22,5 & 38 & 47,5 & 39 & \\
\hline \multicolumn{7}{|c|}{ Dukungan Informasional } \\
\hline Baik & 17 & 21,25 & 43 & 53,75 & 60 & 0,003 \\
\hline Kurang & 13 & 16,25 & 7 & 8,75 & 20 & \\
\hline
\end{tabular}

Pada tabel 3 dapat diketahui bahwa sebagian besar keluarga dengan dukungan penilaian baik, ODGJ berada pada tingkat kekambuhan jarang sebesar $37(46,25 \%)$ responden, dan keluarga dengan dukungan penilaian kurang baik ODGJ dengan tingkat kekambuhan sering sebanyak 19 (23,75\%). Hasil analisa statistic dengan uji chi square didapatkan hasil yang signifikan antara dukungan penilaian dengan tingkat kekambuhan ODGJ dengan $p=0,001$ $(p<0,05)$.

Keluarga dengan dukungan emosional baik, ODGJ berada pada tingkat kekambuhan jarang sebanyak $46(57,5 \%)$ responden, dan dukungan emosional kurang baik dengan tingkat kekambuhan sering sebanyak $11(13,75 \%)$. Berdasar analisa uji chi square didapatkan hasil yang signifikan antara dukungan emosional dengan tingkat kekambuhan ODGJ dengan nilai $p=0,001$ $(p<0,05)$

Pada dukungan instrumental baik, ODGJ dengan tingkat kekambuhan jarang sebanyak $12(15 \%)$ responden, dan pada dukungan emosional kurang baik mengalami tingkat kekambuhan sering sejumlah $12(15 \%)$. Hasil analisa statistic dengan uji chi square ditemukan tidak terdapat hubungan yang signifikan pada dukungan instrumental dengan tingkat kekambuhan ODGJ dengan nilai $\mathrm{p}=0,131$ $(p>0$

Pada dukungan informasional baik, sebagian besar ODGJ berada pada tingkat kekambuhan jarang sebanyak $43(53,75 \%)$ responden, dan keluarga dengan dukungan kurang baik tingkat kekambuhan sering pada ODGJ sejumlah 13 (16,25). Pada uji chi square didapatkan hasil yang signifikan pada dukungan informasional dengan tingkat kekambuhan ODGJ dengan nilai $\mathrm{p}=0,003(\mathrm{p}<0,05)$

\section{PEMBAHASAN \\ Dukungan penilaian}

Hasil analisis statistik didapatkan terdapat hasil yang signifikan antara dukungan penilaian keluarga dengan tingkat kekambuhan orang dengan gangguan jiwa (ODGJ). Sejalan dengan penelitian yang dilakukan oleh Rahmayani \& Hanum, (2018) yang didapatkan bahwa dukungan penilaian secara signifikan berpengaruh terhadap kekambuhan pada pasien skizofrenia.

Keluarga yang memberikan motivasi secara optimal terhadap anggota keluarga yang mengalami gangguan akan mendorong penderita untuk sembuh dan mengurangi terjadinya tingkat kekambuhan. Dukungan penilaian yang diberikan oleh keluarga dapat berupa keluarga memberikan penghargaan atau umpan balik dengan memperlihatkan respon yang positif seperti dorongan dan persetujuan terhadap perasaan penderita. Keluarga yang memberikan perhatian dan bimbingan pada ODGJ secara terus menerus akan memberikan pengaruh yang besar terhadap perkembangan fungsi peran social mereka, sehingga ODGJ mampu berperan secara lebih baik di masayarakat (Hamimi, 2019).

Hasil tabulasi silang menunjukkan pada dukungan penilaian baik sebagian besar responden menunjukkan tingkat kekambuhan yang jarang. Penilaian keluarga dalam memperlakukan ODGJ merupakan hal yang sangat penting, karena 
ini merupakan salah satu factor untuk menghindari kembalinya penderita dirawat di Rumah sakit atau kambuh. Keluarga perlu memberikan perhatian dan support terhadap penderita. Jangan terlalu membatasi ruang gerak atau mengekang penderita untuk bersosialisasi dengan masyarakat sekitar selama penderita tidak mengganggu orang lain (Hariadi et al., 2019). Keluarga dapat memberikan kepercayaan pada ODGJ untuk beraktivitas atau melakukan kegiatan seharihari, karena ini merupakan bentuk dukungan penghargaan yang membuat motivasi tersendri pada ODGJ secara psikologis, sehingga harapannya pasien tidak kambuh kembali

Pada tabulasi silang juga didapatkan hasil dukungan penilaian tidak baik tetapi tingkat kekambuhan ODGJ jarang. Banyak factor yang dapat mempengaruhi tingkat kekambuhan ODGJ, salah satunya adalah kemauan dan motivasi yang besar dari pasien untuk sembuh dan dapat menjalankan aktivitas sehari-hari secara normal sehingga tanpa dukungan keluargapun pasien dapat secara mandiri untuk melakukan aktivitas tersebut. Salin itu juga hasil pengamatan peneliti dilapangan ditemukan beberapa ODGJ yang control ke layanan kesehatan secara rutin, sehingga mereka paham akan informasi yang disampaikan oleh tenaga kesehatan, hal ini yang kemungkinan menyebabkan meskipun tidak ada dukungan dari keluarga tetapi jarang terjadi kekambuhan.

\section{Dukungan Emosional}

Hasil analisa statistik didapatkan terdapat hubungan yang signifikan antara dukungan emosional dengan tingkat kekambuhan ODGJ. Penelitian Tiara et al., (2020) didapatkan hasil yang sama yaitu dukungan emosional yang diberikan keluarga secara signifikan berpengaruh pada tingkat kekambuhan pasien skizofrenia di RSJ lampung

Dukungan emosional yang diberikan keluarga pada ODGJ sangat penting untuk kesembuhan penderita. Dukungan keluarga yang diberikan dapat diberikan melalui bentuk informasi verbal maupun non verbal, bisa berupa saran, melalui bantuan yang nyata ataupun dengan menunjukkan melalui perilaku yang baik oleh orang terdekat dan lingkungan terdekat dari ODGJ. Selain itu dukungan dapat diberikan dalam bentuk kehadiran keluarga ditengah-tengah ODGJ, karena kehadiran keluarga akan memberikan menfaat secara emosional sehingga akan mempengaruhi tingkah laku dari ODGJ itu sendiriSealin itu adanya faktor yang mendukung di luar hubungan antar

Jenis dukungan emosional yang diberikan keluarga dapat berupa perhatian, kasih sayang, dan empati, rasa aman, mengantar pasien berobat, yang dapat membangkitkan semangat terhadap pasien dan mengurangi putus asa (Hamimi, 2019; Yunindra, 2018). Hal ini mengakibatkan pasien akan merasa lebih aman berada dirumah serta merasa mendapatkan kasih sayang dari keluarganya Bentuk dukungan ini memberikan perasaan nyaman, perasaan dicintai oleh keluarga yang lain.

Hasil tabulasi silang menunjukkan sebagian besar responden memiliki dukungan emosional baik dan ODGJ berada pada tingkat kekambuhan yang jarang. Orang dengan gangguan jiwa memerlukan tempat untuk mencurahkan segala perasaan dan isi hati terhadap keluarga. Disini peran keluarga sangat membantu ODGJ untuk meningkatkan rasa percaya diri sehingga ODGJ akan merasa aman, nyaman berada dirumah bersama keluarganya, dengan demikian mekanisme koping yang digunakan ODGJ ketika mempunyai masalah bisa diarahkan pada mekanisme koping adaptif. Penelitian yang dilakukan oleh Sirait et al., (2008) menyatakan koping internal pemecahan masalah bersama pada keluarga kejadian tidak kambuh pada penderita skizofrenia lebih banyak dibandingkan dengan kejadian kambuhnya. Hal ini menunjukkan pemecahan masalah bersama pada keluarga merupakan suatu strategi dimana anggota keluarga dapat berdiskusi tentang suatu masalah secara bersama-sama dengan mencari jalan keluar dari suatu masalah 
Keluarga adalah tempat yang paling tepat, tempat yang aman dan nyaman untuk istirahat dan pemulihan serta membantu dalam penguasaan emosi. Keliat et al., (2011) menuliskan keluarga seharusnya mempunyai sikap positif seperti menerima keadaan pasien, mengahargai dan menumbuhkan sikap tanggung jawab serta tidak mengucilkan pasien. Penelitian yang dilakukan oleh Fadli \& Mitra, (2013) menyatakan bahwa Expressed Emosi (EE) keluarga yang tinggi seperti marah-marah, tidak peka dan bermusuhan, meningkatkan resiko kekambuhan yang lebih besar pada ODGJ. ODGJ memelukan perhatian dan kasih sayang yang lebih dari keluarga akibat menurunnya aktivitas fisik dan mental. Apabila keluarga tidak memberikan dukungan menimbulkan suasana yang tidak menyenangkan sehingga tingkat kekambuhan ODGJ menjadi lebih sering

Pada tabulasi silang juga ditemukan keluarga dengan dukungan emosional kategori baik, tingkat kekambuhan ODGJ pada kategori sering sejumlah 19 orang. Hal ini terjadi kemungkinan ada beberapa factor yang mempengaruhi, bisa dari faktor internal yaitu dari segi emosi ODGJ. Dimana emosi ini tidak hanya dikendalikan oleh keluarga saja melainkan dari pasien sendiri. Salain hal tersebut ada aspek lain yang juga sangat penting untuk diperhatikan yaitu keteraturan dalam pengobatan dan aspek spiritual. Hasil observasi dilapangan masih ditemukan individu yang kurang memperhatikan hal spiritual, masih ditemukan juga beberapa individu yang tidak control secara teratur sehingga proses pengobatan juga terhambat.

\section{Dukungan Instrumental}

Hasil analisa didapatkan bahwa tidak terdapat hubungan antara dukungan instrumental dengan tingkat kekambuhan ODGJ. Hasil ini tidak sejalan dengan penelitian yang dilakukan oleh Hariadi et al., (2019) yang didapatkan bahwa dukungan instrumental keluarga secara signifikan berpengaruh terhadap kekambuhan pasien skizofrenia
Dukungan instrumental merupakan bentuk dukungan serta bantuan penuh keluarga yang dapat berupa pembiayaan, dukungan dalam hal meluangkan waktu untuk pasien, melayani dan mendengarkan segala keluhan pasien. Salah satu contoh betuk dukungan instrumental yang dapat diberikan kelarga pada ODGJ adalah dengan keluarga mengantarkan pasien untuk berobat (Sefrina \& Latipun, 2016)

Rahmayani \& fadhiah (2018) dalam penelitiannya menuliskan salah satu resiko kekambuhan pada ODGJ adalah keluarga yang tidak memberikan perhatian dengan baik pada penderita, masih menomerduakan penderita serta beranggapan bahwa sakit yang dialami ODGJ tidak bisa disembuhkan. Hasil observasi dilapangan didapatkan hal serupa, dimana masih ditemukan beberapa keluarga yang tidak memperdulikan ODGJ, seperti masih ada keluarga yang tidak mengantarkan ODGJ untuk kontrol secara teratur sehingga pasien juga tidak teratur dalam minum obat

Penelitian yang dilakukan oleh Pratama \& Syahrial, (2015) dukungan instrumental yang diberikan oleh keluarga tidak hanya kebutuhan biologis saja, tetapi diharapkan keluarga mampu memfasilitasi semua kebutuhan keluarga pada ODGJ yang meliputi juga kebutuhan spikososial dan spiritual. Secara spikologis yang dapat diberikan seperti memberikan tempat yang nyaman pada anggota keluarga, sehingga rasa sakit yang dialami pasien menjadi lebih ringan, secara social kebutuhan dapat diberikan melalui suport lingkungan masyarakat, sedangkan secara spiritual atau kebutuhan beribadah, dimana keluarga membentu pasien untuk mendekatkan diri kepada tuhannya. Yosep (2010) menuliskan bahwa terapi keagamaan pada ODGJ dapat memberikan banyak manfaat. Kejadian rawat inap pada orang dengan gangguan jiwa berat yang mengikuti kegiatan keagamaan lebih rendah dibandingkan yang tidak mengikutinya. Hal sama didapatkan dari penelitian Sirait et al., (2008) bahwa penderita yang kambuh sebagian besar tidak menggunakan koping spiritual dengan baik, 
sedangkan keluarga yang menggunakan dukungan spiritual yang baik angka kejadian tidak kambuh pada penderita sebesar $75 \%$. Disini dapat disimpulkan bahwa secara bio psiko social dan spiritual adalah dukungan yang penting yang dapat diberikan pada keluarga dengan anggota keluarga yang mengalami gangguan jiwa.

Hasil pengamatan peneliti dilapangan, terlihat masih ditemukan keluarga yang tidak memberikan perhatian terhadap ODGJ. Mereka beranggapan bahwa ODGJ tidak memerlukan perhatian dalam kelembutan ketika berbicara, karena mereka beranggapan ODGJ tidak sadar. Seharusnya keluarga juga mengajak ODGJ keluar rumah sehingga termotivasi untuk dapat berinteraksi kembali dengan orang lain. Selian itu juga seharunya keluarga sesering mungkin mengajak ODGJ untuk bercakapcakap agar mereka dapat memahami apa yang ingin keluarga sampaikan. Sikap positif yang diberikan keluarga akan membantu meningkatkan kesembuhan ODGJ. Merawat keluarga dengan gangguan jiwa memerlukan waktu yang lama dan panjang, kemungkinan untuk perasaan bosan bisa saja muncul dalam keluarga. Dukungan social keluarga sangat diperlukan untuk proses kesembuhan dan mngurangi tingkat kekambuhan ODGJ.

Hasil tabulasi silang didapatkan dukungan instrumental kurang baik sebagian besar tingkat kekambuhan ODGJ jarang yaitu sejumlah 38 responden. Hal ini dimungkinakan dapat terjadi karena motivasi dan kemauan sendiri dari ODGJ untuk sembuh sehingga tanpa dukungan dari keluargapun mereka jarang mengalami kekambuhan

\section{Dukungan Informasional}

Hasil analisa statistik didapatkan hubungan yang signifikan antara dukungan informasional dengan tingkat kekambuhan pada ODGJ. Sejalan dengan penelitian Rahmayani \& Hanum, (2018) yang menyatakan dukungan informasional secara signifikan terhadap pencegahan kekambuhan pada pasien gangguan jiwa.
Keluarga berperan sebagai pemberi dan penyebar informasi terhadap anggota keluarga dengan gangguan jiwa. Informasi yang disampaikan oleh keluarga dapat djadikan acuan untuk mengatasi masalah yang dihadapi ODGJ. Keluarga dapat mencari informasi terkait masalah ODGJ, informasi tersebut dapat bersumber dari tenaga professional, dari bahan bacaan, dari bertanya kepada sumber lain, dimana hal ini diharapkan mampu meningkatkan harapan dan keyakinan dalam usaha mencapai kesembuhan

Memberikan informasi yang penting terhadap anggota keluarga yang mengalami masalah kesehatan dapat diberikan melalui bentuk dukungan informasional. Pada dukungan ini diharapkan keluarga yang mengalami masalah diberikan kelarga pada ODGJ adalah dengan keluarga mengantarkan pasien untuk berobat (Sefrina \& Latipun, 2016)

Rahmayani \& fadhiah (2018) dalam penelitiannya menuliskan salah satu resiko kekambuhan pada ODGJ adalah keluarga yang tidak memberikan perhatian dengan baik pada penderita, masih menomerduakan penderita serta beranggapan bahwa sakit yang dialami ODGJ tidak bisa disembuhkan. Hasil observasi dilapangan didapatkan hal serupa, dimana masih ditemukan beberapa keluarga yang tidak memperdulikan ODGJ, seperti masih ada keluarga yang tidak mengantarkan ODGJ untuk kontrol secara teratur sehingga pasien juga tidak teratur dalam minum obat

Penelitian yang dilakukan oleh Pratama \& Syahrial, (2015) dukungan instrumental yang diberikan oleh keluarga tidak hanya kebutuhan biologis saja, tetapi diharapkan keluarga mampu memfasilitasi semua kebutuhan keluarga pada ODGJ yang meliputi juga kebutuhan spikososial dan spiritual. Secara spikologis yang dapat diberikan seperti memberikan tempat yang nyaman pada anggota keluarga, sehingga rasa sakit yang dialami pasien menjadi lebih ringan, secara social kebutuhan 
dapat diberikan melalui suport lingkungan masyarakat, sedangkan secara spiritual atau kebutuhan beribadah, dimana keluarga membentu pasien untuk mendekatkan diri kepada tuhannya. Yosep (2010) menuliskan bahwa terapi keagamaan pada ODGJ dapat memberikan banyak manfaat. Kejadian rawat inap pada orang dengan gangguan jiwa berat yang mengikuti kegiatan keagamaan lebih rendah dibandingkan yang tidak mengikutinya. Hal sama didapatkan dari penelitian Sirait et al., (2008) bahwa penderita yang kambuh sebagian besar tidak menggunakan koping spiritual dengan baik, sedangkan keluarga yang menggunakan dukungan spiritual yang baik angka kejadian tidak kambuh pada penderita sebesar 75\%. Disini dapat disimpulkan bahwa secara bio psiko social dan spiritual adalah dukungan yang penting yang dapat diberikan pada keluarga dengan anggota keluarga yang mengalami gangguan jiwa

Hasil pengamatan peneliti dilapangan, terlihat masih ditemukan keluarga yang tidak memberikan perhatian terhadap ODGJ. Mereka beranggapan bahwa ODGJ tidak memerlukan perhatian dalam kelembutan ketika berbicara karena mereka beranggapan ODGJ tidak sadar. Seharusnya keluarga juga mengajak ODGJ keluar rumah sehingga termotivasi untuk dapat berinteraksi kembali dengan orang lain. Selian itu juga seharunya keluarga sesering mungkin mengajak ODGJ untuk bercakap-cakap agar mereka dapat memahami apa yang ingin keluarga sampaikan. Sikap positif yang diberikan keluarga akan membantu meningkatkan kesembuhan ODGJ. Merawat keluarga dengan gangguan jiwa memerlukan waktu yang lama dan panjang, kemungkinan untuk perasaan bosan bisa saja muncul dalam keluarga. Dukungan social keluarga sangat diperlukan untuk proses kesembuhan dan mngurangi tingkat kekambuhan ODGJ.

Hasil tabulasi silang didapatkan dukungan instrumental kurang baik sebagian besar tingkat kekambuhan ODGJ jarang yaitu sejumlah 38 responden. Hal ini dimungkinakan dapat terjadi karena motivasi dan kemauan sendiri dari ODGJ untuk sembuh sehingga tanpa dukungan dari keluargapun mereka jarang mengalami kekambuhan

\section{Dukungan Informasional}

Hasil analisa statistik didapatkan hubungan yang signifikan antara dukungan informasional dengan tingkat kekambuhan pada ODGJ. Sejalan dengan penelitian Rahmayani \& Hanum, (2018) yang menyatakan dukungan informasional secara signifikan terhadap pencegahan kekambuhan pada pasien gangguan jiwa.

Keluarga berperan sebagai pemberi dan penyebar informasi terhadap anggota keluarga dengan gangguan jiwa. Informasi yang disampaikan oleh keluarga dapat djadikan acuan untuk mengatasi masalah yang dihadapi ODGJ. Keluarga dapat mencari informasi terkait masalah ODGJ, informasi tersebut dapat bersumber dari tenaga professional, dari bahan bacaan, dari bertanya kepada sumber lain, dimana hal ini diharapkan mampu meningkatkan harapan dan keyakinan dalam usaha mencapai kesembuhan

Memberikan informasi yang penting terhadap anggota keluarga yang mengalami masalah kesehatan dapat diberikan melalui bentuk dukungan informasional. Pada dukungan ini diharapkan keluarga yang mengalami masalah kesehatan dapat diberikan informasi bagaimana cara maningkatkan satus kesehatan maupun bagaimana mencegah terjadinya kekambuhan ulang. Pada ODGJ bentuk dukungan ini dapat diberikan dengan dukungan semangat pada pasien, selalu mendampingi dan mengawasi pasien dalam kegiatan seharihari juga dalam hal pengobatan pasien (Sefrina \& Latipun, 2016)

Dukungan informasional yang diberikan oleh keluarga dapat bersumber dari media masa seperti televisi, majalah, leaflet, keluarga dapat mencari informasi tentang penyakit yang dialami ODGJ, 
pengobatan maupun pencegahan untuk kambuh, bisa dengan tukar menukar informasi dengan keluarga yang lain yang memiliki masalah yang sama, juga dengan bertanya pada perawat maupun dokter (Yunindra, 2018; Sirait et al., 2008) Bentuk dukungan informasional lain yang dapat diberikan adalah dengan memberikan saran, nasihat, petunjuk dan umpan balik (Hartanto, 2014). Komunikasi efektif antara keluarga dengan penderita dapat mengurangi tingkat kekambuhan. Keluarga harus mengetahui informasi yang akurat tentang gejala penyakit, perjalanan penyakit, tatalaksana rehabilitasi, serta strategi kumunikasi dengan penderita dan bantuan secara medis maupun psikologis, guna mencegah kekambuhan. Informasi ini akan membantu individu untuk mengenali masalah lebih mudah

Hasil penelitian dengan tabulasi silang didapatkan responden dengan dukungan informasional baik sebagian besar ODGJ mengalami tingkat kekambuhan yang jarang. Hasil ini sejalan dengan penelitian Sirait (2008), yang menyatakan keluarga yang melakukan pencarian informasi tentang masalah yang dihadapi anggota keluarga dengan baik kejadian tidak kambuh pada penderita lebih besar yaitu sebanyak 75\% dibandingkan dengan yang kambuh hanya $5 \%$.

Hasil tabulasi silang juga didapatkan dukungan informasional baik tetapi tingkat kekambuhan ODGJ sering yaitu sebanyak 17 responden. Purnawan (2008) mengemukakan factor yang mempengaruhi kekambuhan bisa dari internal maupun eksternal. Pada factor internal kemungkinan terjadi dari pengetahuan dan tingkat pendidikan keluarga. Berdasarkan hasil data karakteristik responden rata-rata berpendidikan SD yaitu sejumlah 59 $(78,3 \%)$. Pendidikan mempengaruhi keluarga didalam menyerap informasi, menyelesaikan masalah serta beresiko terhadap ketidakmampuan dalam merawat kesehatannya

\section{KESIMPULAN DAN SARAN}

Penelitian pada keluarga dengan anggota keluarga yang mengalami gangguan jiwa didapatkan kesimpulan terdapat hubungan pada dukungan penilaian, dukungan emosional dan dukungan informasional, sedangkan pada dukungan instrumental tidak didapatkan hubungan yang signifikan. Bentuk dukungan yang diberikan keluarga pada orang dengan gangguan jiwa dapat mengantarkan mereka di kehidupan social yang lebih baik, selain itu juga ODGJ menjadi percaya diri sehingga mereka mampu melakukanaktivias sehari-hari. Dengan demikian diharapkan tingkat kekambuhan ODGJ menjadi berkurang.

Saran yang dapat diberikan mendasar pada kesimpulan diatas adalah, pada keluarga diharapkan untuk rutin mengantarkan ODGJ kontrol ke layanan kesehatan. Pada petugas kesehatan terkait melakukan kunjungan rumah pada penderita sehingga dapat membantu proses perawatan dan penyembuhan ODGJ. Pada masyarakat untuk selalu menberikan dukungan social pada keluarga yang merawat anggota keluarga dengan gangguan jiwa, dengan ini kepercayaan diri keluarga menjadi meningkat sehingga dapat membantu proses kesembuhan ODGJ, dan pada penderita sendiri diharapkan untuk rutin minum obat secara teratur sehingga dapat meminimalkan tingkat kemabuhan.

\section{DAFTAR PUSTAKA}

Chairin, Y. (2018). Gambaran Dukungan Keluarga Kepada Penderita Gangguan Jiwa Skizofrenia Di Rsjd Dr. Rm Soedjarwadi Klaten Jawa Tengah. Skripsi.

Edelman, E. M., Peterson, A., \& Boyer, C. (2010). Patients' Perception Of Family Involvement And Its Relationship To Medication Adherence For Persons With Schizophrenia And Schizoaffective Disorders by. 
Fadli, S. M., \& Mitra, M. (2013). Artikel Penelitian. In Kesmas: Jurnal Kesehatan Masyarakat Nasional (National Public Health Journal) (Vol. 7, Issue 10). https://doi.org/10.21109/KESMAS.V7 I10.6.G8

Hamimi, S. O. (2019). Kontrol Pasien Skizofrenia Di Poliklinik Jiwa Rumah Sakit Jiwa Prof . Dr . Muhammad Ildrem Medan Tahun 2019 Suki Okta Hamimi Politeknik Kesehatan Kementerian Kesehatan Medan Jurusan Keperawatan Prodi D-Iv. Penelitian Kesehatan, 19.

Hariadi, LT, A. N., Alberta, Kiaonarni, \& Ragayasa, A. (2019). Prosiding Seminar Nasional Kesehatan Prosiding Seminar Nasional Kesehatan Poltekkes Kemenkes Surabaya. Prosiding Seminar Nasional Kesehatan Poltekkes Kemenkes Surabaya, 1-5.

Hartanto, D. (2014). Gambaran Sikap Dan Dukungan Keluarga Terhadap Penderita Gangguan Jiwa Di Kecamatan Kartasura. Fakultas Ilmu Kesehatan Universitas Surakarta. http://eprints.ums.ac.id/30909/

Keliat, B. A., Akemat, Daulima, \& Nurhaeni. (2011). Keperawatan Kesehatan Jiwa Komunitas. Jakarta EGC.

Maramis, W. ., \& Maramis, A. . (2009). catatan ilmu Kedokteran Jiwa. Surabaya: Airlangga University Press.

Mubin, M. F., Jiwa, K., Universitas, F., Semarang, M., Ners, P. S., Tinggi, S., \& Kesehatan, I. (2019). Hubungan Kepatuhan Minum Obat Dengan Kekambuhan Pasien Skizofrenia Paranoid. Jurnal Farmasetis, 8(1), 2124.

https://doi.org/10.32583/farmasetis.v8i 1.493
Nasir, A., \& A Muhith. (2011). Dasar-dasar Keperawatan Jiwa: Pengantar dan Teori. Jakarta Salemba Medika.

Pratama, Saifuddin I.Y, \& Syahrial. (2015). Hubungan Keluarga Pasien Terhadap Kekambuhan Skizofrenia Di Badan Layanan Umum Daerah (Blud) Rumah Sakit Jiwa Aceh | Pratama | Jurnal Kedokteran Syiah Kuala. Jurnal Kedokteran Syiah Kuala Volume 15 Nomor 2 Agustus 2015. http://erepository.unsyiah.ac.id/JKS/article/vi ew/3258/3082

Purnawan. 2008. Dukungan Keluarga. Bandung. PT. Remaja Rosdakarya

Rahmayani, R., \& Hanum, F. (2018). Analisis Dukungan Sosial Keluarga Terhadap Pencegahan Kekambuhan Gangguan Jiwa Di Wilayah Kerja Puskesmas Sukajaya. Sel Jurnal Penelitian Kesehatan, 5(2), 77-89. https://doi.org/10.22435/sel.v5i2.1493

Riskesdas. (2018). Hasil Utama Riskesdas Penyakit Tidak Menular 2018, Hasil Utama Riskesdas Penyakit Tidak Menular

Sefrina, F., \& Latipun. (2016). Hubungan Dukungan Keluarga dan Keberfungsian Sosial pada Pasien Skizofrenia Rawat Jalan. Jurnal Ilmiah Psikologi Terapan, 04(02), 140-160.

Sirait, A., Koping, P., Terhadap, K., Relaps, K., Skizofrenia, P., \& Sempurna, R. (2008). Asima Sirait: Pengaruh Koping Keluarga Terhadap Kejadian Relaps Pada Skizofrenia Remisi Sempurna..., 2008 USU e-Repository (C) 2008.

Tiara, C., Pramesti, W., Pebriyani, U., \& Alfarisi, R. (2020). Hubungan Konsep Dukungan Keluarga Dengan Tingkat Kekambuhan Pada Paisen Skizofrenia Relationship Concept of Family 
Support with Recurrence Rate in Schizophrenia Artikel info Artikel history. Juni, 11(1), 522-532. https://doi.org/10.35816/jiskh.v10i2.3 39

World Health Organization. (2018). Global Status Report on Alkohol and Healt. 